\title{
Death Penalty Legislation in China and Indonesia Under International Human Rights Law Perspective
}

\author{
Dodik Setiawan Nur Heriyanto dan Huang Gui \\ Faculty of Law, Islamic University of Indonesia; Faculty of Law, University of \\ Debrecen and Minzu University of China \\ Tamansiswa Street No. 158 Yogyakarta; Kassai Street No. 26 Debrecen \\ dodiksetiawan@uii.ac.id; hg_0125@126.com
}

\begin{abstract}
Most of countries in the world have terminated the death sentence for the sake of respecting the human rights internationally as the universal human rights. In fact, China and Indonesia have the different practice in the executing the death penalty for certain crimes. Using the normative legal research method, this research analysed two core issues including to what extent of the international protection of human rights in China and Indonesia. This study is to analyze two main issues: to what extent the international protection of human rights in China and Indonesia and how the law and the international protection of human right impact the policy of implementation of death sentence in China and Indonesia. This study concluded two points: first, there was a difference in the implementation of human rights both in China and in Indonesia particularly in implementing the death sentence in both countries in which both apply certain limitation in implementing the death sentence. Second, the approval of the International Kovenan about the civil right and political right becomes the basic parameter to what extent those two countries regulate the policy of death sentence and to what extent of the attempt of those two countries in making its domestic law harmonious with the international human right.
\end{abstract}

Keywords: China, death sentence, human rights, Indonesia

\section{Abstrak}

Sebagian besar negara di dunia menghapuskan hukuman mati atas dasar penghormatan hak asasi manusia yang sudah diterima secara internasional sebagai hak asasi manusia universal. Faktanya, Tiongkok dan Indonesia memiliki praktek yang berbeda dalam pelaksanaan hukuman mati untuk kejahatan tertentu. Dengan menggunakan metode penelitian hukum normatif, studi ini mengkaji dua masalah utama yaitu: sejauh mana perlindungan hak asasi manusia di Tiongkok dan Indonesia serta bagaimana hukum dan hak asasi manusia internasional mempengaruhi kebijakan pemberlakuan hukuman mati baik di Tiongkok dan Indonesia. Studi ini menyimpulkan dua hal: pertama, terdapat perbedaan pelaksanaan hak asasi manusia baik di Tiongkok dan Indonesia khususnya dalam menerapkan hukuman mati kedua negara yang mana keduanya menerapkan batasan tertentu dalam pelaksanaan hukuman mati. Kedua, pengesahan Kovenan Internasional tentang Hak Sipil dan Politik menjadi parameter dasar terhadap seberapa jauh kedua negara tersebut memberlakukan kebijakan hukuman mati dan seberapa besar usaha kedua negara dalam mengharmonisasikan hukum domestiknya dengan hukum hak asasi manusia internasional. 


\section{Introduction}

According to the report of Amnesty International, by the end of 2014, there were 58 states still retaining the death penalty in the world including China and Indonesia, ${ }^{1}$ and at least 1634 people were executed in 25 countries in 2015 . This facts represent a stark increase on the number of executions recorded in 2014 of more than $50 \% .^{2}$ Since 2007, a series of four resolutions on Moratorium on the Use of the Death Penalty adopted by the General Assembly respectively in 2007, 2008, 2010, and 2012, which urge States to respect international standards that protect the rights of those facing the death penalty, to progressively restrict its use and reduce the number of offences. ${ }^{3}$ Nowadays, more and more states are moving towards a future without the death penalty. ${ }^{4}$ So far, more than 140 member states of the United Nations with a variety of legal systems, traditions cultures and religious backgrounds, have either abolished the death penalty or do not practice it. 5

Legislation to abolish the death penalty is important to uphold fundamental right to life. This non-derogable right is enshrined from article 3 of the Universal Declaration of Human Rights (UDHR) which stipulates that "everyone has the right to life, liberty and security of person"6 and reinforced in the Article 6 of the International Covenant on Civil and Political Rights which stipulates that "every human being has the inherent right to life. This right shall be protected by law. No one shall be arbitrarily deprived of his life. ${ }^{7}$

As a matter of fact, Asian countries have been the location of at least 85 percent and as many as 95 percent of the world's executions. ${ }^{8}$ Surprisingly in 2015, more

\footnotetext{
1 Amnesty International, Death Sentences and Executions in 2014 (ACT 50/001/2015), https://www.amnesty.org/en/documents/act50/0001/2015/en/ (accessed January 3rd, 2016), p.64.

2 Amnesty International, Death Penalty 2015: Facts and Figures, https://www.amnesty.org/en/ latest/news/2016/04/death-penalty-2015-facts-and-figures/ (accessed January 5th, 2016). This figure excludes the number of executions believed to have been carried out in China; due to it is considered a state secret.

3 See Resolutions on Moratorium on the Use of the Death Penalty adopted by the General Assembly, on the report of the Third Committee (A/62/439/Add.2; A/63/430/Add.2; A/65/456/Add.2; A/67/457/Add.2; A/69/488/Add.2 and Corr.1).

4 Penal Reform International, Alternative to the Death Penalty Information Pack, http://www.penalreform.org/wp-content/uploads/2013/06/PRI_Lifers_Info_Pack.pdf (accessed January 10th, 2016), p.5.

${ }^{5}$ Amnesty International, Death Sentences and Executions in 2014 (ACT 50/001/2015), Loc. Cit.

${ }^{6}$ Universal Declaration of Human Rights (UDHR), 1948, art.3.

${ }^{7}$ International Covenant on Civil and Political Rights (ICCPR), 1966, art. 6(1).

${ }^{8}$ Franklin E. Zimring and David T. Johnson, "Law, Society, and Capital Punishment in Asia", Punishment \& Society, No. 2, Vol. 10, 2008, p.104. See also David T. Johnson and Franklin E. Zimring, "Death Peanalty Lesson from Asia", The Asia-Pacific Journal, Issue. 39, Vol.7, 2009, pp.1-28.
} 
than one thousand convicts were executed in China. ${ }^{9}$ As well as Indonesia, 14 convicts were also executed death penalty in 2015. ${ }^{10}$ Those executions are actually legalized through its domestic legislations. Death penalty has legitimate source through its domestic laws to be one of the primary punishment measures and claimed to have important role in criminal control and maintaining society stability. ${ }^{11}$ These facts are inconsistent with their concern with human rights protection in which they already bound with multilateral human rights treaties.

Both Indonesia and China are on the way to reform their domestic laws by putting into priority to abolish capital punishment as part of global effort to honor human rights protection. Those legislations and its development are the main focus of this study to measure how far both of this countries ready to reform their domestic legislations for the sake of protecting human rights and taking the relevant international responsibilities. Importantly, this study also uses relevant international human rights law treaties to especially ICCPR to acknowledge development stage of both countries in harmonizing its domestic laws with the universally recognized standards of human rights.

\section{Problem Statements}

This study will answer two problem statements through comprehensive legal analysis. The two problem statements are: first, how far the protection of human rights in China and Indonesia particularly in the implementation of the death penalty policy? Second, how does the international human rights law influence Chinese and Indonesian domestic legislations which legitimize death penalty?

\section{Research Purposes}

This research has two main purposes, such as: first, to emphasize the protection of human rights in China and Indonesia particularly in the implementation of the death penalty policy? Second, to analyze the influence of

\footnotetext{
9 Amnesty International, Death Sentences and Executions in 2015(ACT 50/3487/2016), https://www.amnesty.org/en/documents/act50/3487/2016/en/ (accessed May 15 th 2016 ), p.26.

${ }^{10}$ Ibid.

${ }^{11}$ Hong Lu and Terance D. Miethe, China's Death Penalty: History, Law, and Contemporary Practices, Routledge, New York and London, 2008, p.27.
} 
international human rights law in Chinese and Indonesian domestic legislations which legitimize death penalty.

\section{Research Method}

This study applies normative legal research by using statute and comparative approaches to answer the problem statements above. The international human rights law treaties become the key regulation in this research. It will be the core analyzes to find out the real development of domestic laws in China and Indonesia to comply universal human rights standards by abolishing capital punishment. This statutory approach, indeed, plays important role to reveal the existence of this domestic laws.

To obtain comprehensive legal conclusion, this study also employs comparative approach to compare between Chinese and Indonesian domestic laws importantly to gain the root of the problems on why both of this countries still executing capital punishment. Comparative study on both of these domestic laws are rare in academic reference and thus as researchers we hope that this study could be part of academic understanding to discover Chinese and Indonesian legislations on death penalty.

This study exploits legal materials which consist of primary, secondary, and tertiary research materials. These legal materials are to be collected and presented by descriptive and qualitative analysis.

\section{Discussion and Result}

\section{Human Right Protection and Death Penalty Legislations in China}

\section{The Development of Human Rights in China}

Different Chinese scholars have different views about the development stages of human rights in China. Some scholars believe that the development of human rights in China could be divided into four stages. The first stage is in the period of from the founding of People's Republic of China (PRC) in 1949 to reform and opening up in 1979, in which Chinese government had made great contributions to in terms of independents and development of developing countries. The period of from 1979 to 1990 is the second stage of human rights development in China, in 
which Chinese government participated in promoting human rights and gradually accepted the international standards of human rights and participated international human rights regime. The third stage is in the period of 1990s, in which Chinese government broadly took part in international human rights affairs and promoted the development of human rights while the Chinese government devoted to safeguard state sovereignty. The fourth stage is in $21^{\text {st }}$ centuries, in which Chinese government had done or will further promote the international development of human rights in the world. ${ }^{12}$

In November, 1991, Information of Office of the State Council of the PRC launched the first White Papers on Human Rights in China, which is considered as a great mark of the fundamentally theoretical and practical changes of Communist Party's and government's concepts of human rights. By White Papers, the notion of human rights was firstly used by the Chinese government, and it was first time that Chinese government summarizing and commenting the history of China's revolution, development and reform and opening up in the period of after 1997 with the perspective of human rights, and started firstly the situation of human rights in China and Chinese government's human rights' opinions according to real national conditions. White Papers completely denied the position of Chinese government on human rights that only pertaining to bourgeoisie' slogan, and insisted that human rights also pertains to socialist and is socialist' 'lofty ideals'. ${ }^{13}$

After 1991, human rights developed very fast in China. On one hand, Chinese government gradually acknowledged and accepted some international human rights covenants and started to participate in some international human rights treaties. For example, Chinese government signed ICCPR (signed in 1998 but no ratification until now) and ICESCR ${ }^{14}$ (signed in 1997 and ratified in 2001). On the other hand, since 1979, legal institution-building was put on the agenda and Chinese government commenced to emphasize on legislation. For example, China adopted the present Constitution in 1982, which plays an important role in

${ }^{12}$ Dong Yunhu and Chang Jian, 60 Years of Human Rights Construction in China, Jiangxi People's Publishing House, Jiangxi, 2009, p.78.

13 Information of Office of the State Council of the PRC, White Papers on Human Rights in China, http://www.chinahumanrights.org/html/2014/WP_0724/36.html (accessed 8 January 2016).

${ }^{14}$ International Convention on Economic, Social, and Cultural Rights (ICESCR), 1966. 
protecting human rights. The first Criminal Law and Criminal Procedure Law were adopted in 1979, and other such Civil Law, Civil Procedure Law, Administration Law and Administration Procedure Law were successfully adopted in 1980s. These laws showed a great progress of China's legal-building and in this period. China's understanding on human rights just remained at the level of self-explanation and using it for China own purpose. Though it lacked of substantial but it has effective step to improve human rights situation by legislation and judicial practice. ${ }^{15}$

A significant milestone of the development of human rights in China is the provision of 'the state respects and preserves human rights'16 that was contained in PRC's Constitution. In 2004, Constitution of PRC firstly contains the provision of human rights protection, and makes the human rights to become a legal concept from political notion, and become the citizens' and national wills and value of state construction and development and constitutional principle. A new chapter of human rights protection was commenced since 2004, and a majority of substantial measures of human rights protection and most of them is emphasized by the Party's reports. For example, at the 16th National Congress of the Communist Party of China (CPC) in 2002, the President at that time, Jiang Zemin stated in his report that '... human rights are respected and guaranteed'17 At the CPC's $17^{\text {th }}$ and $18^{\text {th }}$ National Congress in 2007 and 2012, the President at that time, Hu Jintao also emphasized the same spirit to respect and safeguard human rights, and ensure the equal right to participation and development for all members of society in accordance with the law. ${ }^{18}$ Later, in 2014 , the $4^{\text {th }}$ Plenary Session of the $18^{\text {th }}$ Central Committee of the CPC again declared its intention to 'strengthen the judicial protection of human rights; strengthen the consciousness of the importance of respecting and protecting human rights in society, and provide complete channels

15 Dong Heping, "Some Thoughts on the Problems in China's Human Rights Protection", Law Science, No.9, 2012, p.91.

${ }^{16}$ Constitution of People's Republic of China, 2004, art. 33 (3).

${ }^{17}$ Jiang Zemin, Build a Well-off Society in an All-Round Way and Create a New Situation in Building Socialism with Chinese Characteristics, http:/ / history.people.com.cn/GB/205396/15040127.html (accessed February 3rd, 2016).

18 Hold High the Great Banner of Socialism with Chinese Characteristics and Strive for New Victories in Building a Moderately Prosperous Society in all Respects, Scientific Outlook on Development, http:// news.xinhuanet.com/english/200710/24/content_6938749_11.htm (accessed February 5th, 2016). Firmly March on the Path of Socialism with Chinese Characteristics and Strive to Complete the Building of A Moderately Prosperous Society in All Respects, $18^{\text {th }}$ CPC National Congress, http://news.xinhuanet.com/english/special/18cpcnc/2012-11/17/c_131981259_4.htm (accessed February 5th, 2016). 
and methods to obtain relief for citizen's rights. ${ }^{\prime 19}$ To some extent, the concept of human rights is getting a fast and great development and Chinese government has been reforming its legal system to protect human rights, including death penalty reform.

\section{The Influence of Human Rights on Death Penalty Reform in China}

In China's history, the proposal of death penalty abolition had ever been made twice times: one was made by the Article 10 (9) of the Communist Party of China's Proposals on the Current Political Situations on 15 June 1922, which provided that "reforming the judicial system, abolishing death penalty and repealing corporal punishment"20; the second one was made by the political report of CPC's $8^{\text {th }}$ National Congress on 15 September 1956, which stated that "all the death cases shall only be sentenced or approved by the Supreme People's Court (SPC), so that we can gradually achieve the goal of completely abolishing death penalty."21 These two proposals were made in different stages. The first time was made in the early days of the Communist Party of China before the foundation of New China, and it was, to a great extent, "only for toppling the reactionary regime or some parts of the political super structure."22 The second one was in the early of founding of new China, and importantly, the socialist transformation was just finished and it started socialist regime in 1956 and it was preparing for the communist system, ${ }^{23}$ therefore, the proposal of death penalty abolition was only the Party's political plan and ideas. But, after that, China embroiled in great turbulences resulted in by mistakes made by the national leaders, for example, China launched the Anti-Rights Campaign in 1957, and then the economic program, "Great Leap Forward", was announced in 1958, and then, another disaster of social and political movement, Cultural Revolution, was launched since 1966 . These turbulence actually had made the legal

${ }_{19}$ The CCP Central Committee Decision Concerning Some Major Questions in Comprehensively Moving Government of the Country According to the Law Forward, http://www.cssn.cn/fx/fx_ttxw/201410/t20141030_1381703.shtml (accessed February10th, 2016).

20 Communist Party of China's Proposals on the Current Political Situations, http://www.china.com.cn/guoqing/2012-08/28/content_26745372.htm (accessed February 11th, 2016).

${ }^{21}$ Liu Shaoqi, The Political Report of CPC's $8^{\text {th }}$ National Congress, in The Selected Work of Liu Shaoqi, http:/ / cpc.people.com.cn/GB/69112/73583/73601/73624/5069218.htmlm (accessed February 15th, 2016).

${ }^{22}$ Lu Jianping, "The Death Penalty Reform in China in Light of Human Rights", Journal of Beijing Normal University (Social Science Edition), No.3, 2015, p.126.

${ }^{23}$ Liu Shaoqi, Loc. Cit. 
construction of China nearly suffer from extinction. At one time, illegally detaining and lynch overflowing, fascist dictatorship running wild, a large number of frameup, false and wrong cases had been made.24 Therefore, the political goal of abolishing death penalty was far from the expectation. Furthermore, after 1958, the criminal legislation work was weakened, except several amnesty decrees, no special criminal law had been issued, and even non-criminal laws issued had seldom included criminal law norms too. ${ }^{25}$ So, the political goal of abolishing death penalty or strict the use of death penalty cannot be implemented by the legislation and judicial practice.

Since the provision of 'the state respects and preserves human rights' was contained in Constitution, China, in a true sense, started to change the death penalty system from the legislation and judicial aspect. China implements the death penalty policy of "retaining death penalty, but strictly control and cautiously use the death penalty". ${ }^{26}$

According to the Amnesty International report, "China's executions remain in the thousands annually and is the world's top executioner." 27 In this sense, the reform of death penalty in China will contribute a great meaning to human rights development in the world. In another words, if death penalty in China is effectively limited and even repealed de facto and de jure, the movement of abolishing death penalty in the world will be made a substantial progress. So far, Chinese government has already taken three significant steps to reform the death penalty system since 2007. On 1 January 2007, the power to review the death sentences was withdrawn by the Supreme People's Court of PRC (SPC) from the local High Courts in every province and Military Courts; 28 and then, on 8 February 2010, the SPC enacted the Opinions on the Implementation of the Criminal Police of

\footnotetext{
${ }^{24}$ Gao Mingxuan and Zhao Bingzhi, The Evolution of Chinese Criminal Legislation, Law Press·China, Beijing, 2007, p.70.

${ }_{25}$ Ibid, p.69.

${ }^{26}$ Resolutions of the Communist Party of China's Central Committee on Major Issues Regarding the Building of $A$ Harmonious Socialist Society, http://cpc.people.com.cn/GB/64093/64094/4932424.html (accessed March 2nd, 2016).

${ }^{27}$ Ibid.

28 The Supreme People's Court of PRC Answering the Ten Detail Questions about the Power to Review the Death Sentences was Withdrawn, http://www.law-lib.com/fzdt/newshtml/21/20061230095003.htm (accessed March 4th, 2016).
} 
Appropriately Combining Leniency and Severity, of which the Article 29 provides that "strictly controlling and the use of death penalty under the law, unifying the standards to settle capital case, and so that the death sentence can only be imposed on a few offenders who commit the most serious crime ... for those offenders who commit the most serious crime and shall be sentence to death, a death sentence shall be given by law ... for those offenders should be sentenced to death, if, according to the law, the immediate execution is not necessary, he or she should not be given immediate execution". ${ }^{29}$ Based on this provision, we can see that the death penalty can only be imposed on the a few offenders and only for the most serious crimes.

On 24 June 2010, SPC, Supreme People's Procuratorate, and the Ministry of Public Security together promulgated the Regulations on Major Issues on Reviewing and Judging Evidences while Handling Death Cases and the Regulations on the Major Issues on Excluding Illegally Obtained Evidence While Handling Criminal Cases. These two regulations increase the applicable conditions of evidences in the death cases, and it, to a great extent, limits the use of death penalty. The aims of these two regulations are to control death penalty from the aspect of criminal procedure. This is the first step from the judicial perspective to control death penalty.

The second and third step is taken in 2011 and 2015 respectively, and they reform the death penalty system from the legislation aspect. On 15 February 2011, the Eighth Amendment to Criminal Law was adopted, and abolished the death penalty for 13 economic and nonviolent crimes, reducing the number of crimes punishable by death from 68 to 55, and banned capital punishment for offenders over the age of 75 . It started a process of gradually abolishing the death penalty in China. The Ninth Amendment, which was adopted on August 29th 2015, and it further reduces the amount of crimes punishable by death stipulated by specific provisions of Criminal Law from 55 to 46, and improve the executive conditions of which the suspension was revoked and imposed immediate execution, which is a reform of great significance for Chinese present death penalty system. ${ }^{30}$ Shortly,

\footnotetext{
${ }^{29}$ The Opinions of Supreme People's Court on the Implementation of the Criminal Police of Appropriately Combining Leniency and Severity, Court Promulgating, No. 9, 2010, art. 29.

${ }^{30}$ Huang Gui, "Death Penalty in China after the Ninth Amendment: Legislatively Abolishing and Judicially Limiting”, Journal of Forensic Science and Criminology, Volume 4, Issue 3, 2016, p.1.
} 
these steps are not enough and need further government efforts to completely repeal the death penalty.

Noting to the fact that the Chinese government conceals the exact number of those executed in death penalty from publication. Such publication, from the Chinese government side, would harm China reputation in international community. This number perhaps could be higher than the data from Amnesti International - some scholars estimates more than 15.000 per year. ${ }^{31}$ If this number is true, such legislative reform to abolish death penalty would remain uncertain.

China actually takes a position that capital punishment merely to be hold for "the most serious crime" with direct basis from article 6 (2) of ICCPR and Safeguard $1^{32}$ of the Safeguards Guaranteeing Protection of the Rights of those Facing the Death Penalty. This international measure is in line with the 1997 Chinese Criminal Code in which imposing death penalty limited to the most serious crime. Since characterization of the most serious crime is unclear in international level including in ICCPR, then Chinese legislations imposed capital punishment for 68 types of crime which claimed still in the category of "the most serious crime". Those wide range of crimes punishable by death penalty is a sign of slow movement to abolish death penalty. Such legislations that contains capital punishment is a tricky policy from the Chinese government to maintain imposing capital punishment due to the flexibility of ICCPR.

\section{Human Right Protection and Death Penalty Legislations in Indonesia}

\section{The Development of Human Rights in Indonesia}

Protection of fundamental human rights has entered into a good level in Indonesia. From the legislations perspective, the fulfillment and protection of human rights has been guaranteed by article 28 of 1945 Constitution. This basic article from constitution then eleborated specifically through various legislations in which Law No. 39 Year 1999 as the basic legislation that contains the protection of human rights at national level. Law No. 39 Year 1999 specifies rights and freedom

\footnotetext{
31 See David T. Johnson and Franklin E. Zimring, Op. Cit., pp.234-242.

32 Article 6 (2) of ICCPR stipulates that "In countries that have not already abolished the death penalty, sentence of death may be imposed only for the most serious crimes...".
} 
of each citizens that acomodates universal rights and freedoms contain in multilateral treaties ratified by Indonesia such as UDHR, ICCPR, and CESCR. ${ }^{33}$ For technical implementation of this Law, the Government also enacted specific laws to support the enforcement of human rights, in example the Law No. 35 Year 2014 on Children Protection and Law No. 11 Year 2002 on Juvenile Criminal Justice System. Some other laws also contains basic human rights as the philosophical basis of the enforcement, in example Law No. 8 Year 1999 on Consumer Protection and Law No. 23 Year 2004 on the Elimination of Domestic Violence.

The law governing human rights are not only in the legislative law but also outspread into another form of government regulations including local laws. It means that from central to local governments are ready to guarantee the enforcement of human rights. Certain local laws even regulate certain local laws that relevant to address human rights issues at the region. The best example is the Local Law of Yogyakarta Province No. 6 Year 2011 on the Protection of Children Living on the Street that solving local problem to decrease the number of children who living on the street through actual actions to prevent children from the risk living on the street, to allocate local government budget to support children access to get their basic rights, and to reintegrate children who lives on the street to their family. ${ }^{34}$

Based on judicial perspective, to enforce the law of human rights, Indonesia enacted the Law No. 26 Year 2000 about Human Rights Court. This Court has the main authority to trial gross violation of human rights including the crime of genocides and crimes against humanity. This law focuses on the serious violation of human rights which not only occured before the law was enacted but also the similar cases of violations which will occur in future. 35

In specific about the right to life, though universally this right is basically nonderogable right but Indonesia takes a position to limit the right to life with clear

${ }^{33}$ In the Consideration part of the Law No. 39 Year 1999, it is stated that: "d. whereas as a member of the United Nations, the nation of Indonesia has a moral and legal responsibility to respect, execute, and uphold the Universal Declaration on Human Rights promulgated by the United Nations, and several other international instruments concerning human rights ratified by the Republic of Indonesia."

${ }^{34}$ Local Law of Yogyakarta Province No. 6 Year 2011 on the Protection of Children Living on the Street, art.6.

${ }^{35}$ Junaedi, "The Existence of Human Rights Court as A National Effort to Eliminate the Severe Violation of Human Rights in Indonesia”, Indonesia Law Review, Vol. 2., 2014, p.176. 
legal position. This position is based on Indonesian People Consultative's Assembly Decree No. XVII/MPR/1998 that Indonesian perspective and position to the human rights must be based on religious values, universally moral values, and cultural values, with a true basis on Pancasila (the philosophical foundation of the country) and 1945 Constitution. In line with the spirit of this decree, the explanation of article 9 paragraph (1) of the Law No. 39 Year 1999 confirmed that the right to life could be limited by only two extraordinary reasons: reasonable medical facts during the abortion procedure (merely to safe the life of the women/mother) and court decision on death penalty. ${ }^{36}$ This limitations must be legally based on relevant legislations and court decisions.

\section{The Influence of Human Rights on Death Penalty Reform in Indonesia}

Indonesia has ratified important human rights treaties such as ICCPR (ratified in 2006), ICESCR (ratified in 2006), Convention on the Elimination of All Forms of Discriminations Against Women (ratified in 1984), Convention on the Rights of the Child, and International Labor Organization Conventions. This ratifications proof Indonesian strong efforts to promote and protect human rights. However, to protect the right to life which has clear legal stand in UDHR and ICCPR, Indonesia has not yet abolished death penalty.

In 2015, based on the Report of Amnesty International, Indonesia ranked 9th position which has sentenced death penalty to 14 convicts. ${ }^{37}$ In recent drug trafficking case, the Indonesian government plans to execute 14 convicts who seriously violates the Law No. 39 Year 2005 on Narcotics Drugs. ${ }^{38}$ Indonesia believes that death penalty has deterrent effect and this reason has pro and contra. ${ }^{39}$ As Lynch by quoting comparative example from Professor Fagan which stated that:

"Professor Fagan discussed the apparent detterent effect of capital punishment in Southeast Asia by comparing the experiences of Indonesia and Singapore. Despite Indonesia's much larger population, Singapore excecuted almost fifteen times as many convicts as did Indonesia between 1999 and 2005.

\footnotetext{
${ }^{36}$ Law No. 39 Year 1999 on Human Rights, art. 9 (1).

37 Amnesty International, "Death Penalty 2015: Facts and Figures", Loc. Cit.

38 Indonesia: Stop Imminent Excecutions, Human Right Watch, 2016, https://www.hrw.org/news/2016/07/27/indonesia-stop-imminent-executions (accessed July 30th, 2016).

39 Todung Mulya Lubis and Alexander Lay, Kontroversi Hukuman Mati: Perbedaan Pendapat Hakim Konstitusi, Kompas Media Nusantara, Jakarta, 2009.
} 
If capital punishment had a deterrent effect on drug trafficking, this would lead to less drug trafficking, and therefore higher wholesale drug prices, in Singapore. However, wholesale drug prices for both cocaine and heroin were significantly higher in Indonesia than in Singapore from 2003 to 2006, and drugs generally were more prevalent in Singapore than Indonesia in that period, indicating that drug trafficking was not deterred as a result of Singapore's high levels of capital punishment. ${ }^{40}$

There are 10 types of crime based on Indonesian Criminal Code that possible to be sentenced capital punishment, such as: assault actions to President and Vice President (article 104), persuading other country to take hostility with Indonesia (article 111 paragraph (2)), supporting the enemy in the time of war (article 124 paragraph (3)), assaulting the King and the President of other countries either premeditated action or resulted death (article 140 paragraph (3)), premeditated murder (article 340), rustling which resulted serious injury or death (article 365 paragraph 4), extortion which resulted serious injury or death (article 365 paragraph 2), and sea/river hijacking which resulted death (article 444). Outside the Criminal Code, death penalty also could be sentenced for criminal actions under specific central government laws, including economic crimes (Law No. 21 Year 1959), abuse of political powers (Law No. 11 Year 1963), drug traffickers (Law No. 39 Year 2005), Act of Terrorism (Law No. 9 Year 2013), and Crime of Air Transport (Law No. 4 Year 1976). From those all type of crimes, it indicates that although Indonesia has ratified ICCPR but death penalty still possible to be sentenced for criminal actions outside the category of gross violation of human rights.

Indonesia has moral obligation as the ICCPR to promote and protect the basic human rights under its normative rule and direction. ${ }^{41}$ Eventhough death penalty could be sentenced for crime which has no element of the gross violation of human rights such as economic crime and drug traffickers, but Indonesia has been maintained to take careful steps in adopting death penalty to derive the right to life of the convict. This careful steps could be drawn from: first, the reasonable

\footnotetext{
${ }^{40}$ Coman Lynch, "Indonesia's Use of Capital Punishment for Drug-Trafficking Crimes: Legal Obligations, Extralegal Factors, and the Bali Nine Case", Columbia Human Rights Law Review, Vol. 40, 2009, pp.536-357.

41 Todung Mulya Lubis and Alexander Lay, Op. Cit., pp.326-329.
} 
legislative analysis for certain crimes which could be sentenced death penalty. This analysis can be found from academic analysis report of the drafting of the legislation. For example, in determining death penalty for drug trafficker, the House of Representative agreed from the real fact that the increasing number of the illegally drug users only could be solved by high level punishment to provide deterrent effect. ${ }^{42}$ Moreover, the Court decision of convict to be sentenced death penalty is not under the political influence but based on the true facts in the trial and independent judge decision. Second, openness of information toward the execution of death penalty. The Indonesian government has maintained the openness system to show the its commitment to combat serious crime. ${ }^{43}$ It means that the government or NGO both nationally and internationally or even the United Nations could acknowledge the real facts and improvement process specifically to achieve the government willingness to abolish capital punishment. ${ }^{44}$

\section{Conclusion}

Most of the countries in the world has abolished death penalty on the basis to promote and protect the right to life as guaranteed by UDHR and ICCPR. Unfortunately, based on report from Amnesti International Asia Pacific countries are most prolific place of death penalty. As the country which still retain death penalty, China and Indonesia have the same effort to reform its legislations to become place with zero number for death penalty. However, in practice, the number of convicts are still high in number annually showing that their good willingness to abolish death penalty are far to achieve.

This study comes into two conclusions that first, China and Indonesia have applied different policies in the protection of human rights. In China, constitutionally place the human rights from political notion into a legal concept (rule of law) meaning that the government seriously undertakes the human rights in greater progress. However, in practice, Chinese government in contrast still

\footnotetext{
42 Andi Hamzah, Pidana Mati di Indonesia: Di Masa Lalu, Kini, dan Masa Depan, Ghalia Indonesia, Jakarta, 1984. Tina Asmarawati, Hukuman Mati dan Permasalahannya di Indonesia, Deepublish, Yogyakarta, 2015, pp.67-71.

43 Most importantly, Indonesian government also has established rule as the guideline to process the execution of death penalty and guarantee the fair trial for convicts. See Law No. 5 Year 1969 on the Procedure of the Execution of Death Penalty which sentenced by Criminal Courts and Military Courts.

44 Tim Imparsial, Jalan Panjang Menghapus Praktek Hukuman Mati di Indonesia, Imparsial, Jakarta, 2004.
} 
maintaining policies that far from the values of human rights such as the restriction of freedom of expression through censorships and most importantly although data on the death penalty has been considered as a state secret, many experts estimate that its number could be higher than the data from Amnesti International. This condition is quite different in Indonesia where its constitution guarantee the human rights protection as well as in practice the government maintains to promote the human rights through various legislations and limits the enforcement of the death penalty by legal and reasonable limitations.

Second, focusing to the ratification and implementation of ICCPR as one of the substantial treaty to promote the right to life, this study found that China as the non-participant of ICCPR takes death penalty in secrecy number and with unclear real efforts. Flexibility of ICCPR enforcement on the right to life used by the Chinese government to support their position in imposing death penalty. Indonesia as participant of ICCPR chooses to carefully legislate and enforce capital punishment. Moreover, the openness of Indonesia on the death penalty position and situation indicate its strong willingness to adhere the international obligations.

\section{References}

\section{Books}

Hamzah, Andi, Pidana Mati di Indonesia: Di Masa Lalu, Kini, dan Masa Depan, Ghalia Indonesia, Jakarta, 1984.

Tina Asmarawati, Hukuman Mati dan Permasalahannya di Indonesia, Deepublish, Yogyakarta, 2015.

Lu, Hong and Miethe, Terance D., China's Death Penalty: History, Law, and Contemporary Practices, Routledge, New York and London, 2008.

Lubis, Todung Mulya and Lay, Alexander, Kontroversi Hukuman Mati: Perbedaan Pendapat Hakim Konstitusi, Kompas Media Nusantara, Jakarta, 2009.

Mingxuan, Gao and Bingzhi, Zhao, The Evolution of Chinese Criminal Legislation, Law Press.China, Beijing, 2007.

Tim Imparsial, Jalan Panjang Menghapus Praktek Hukuman Mati di Indonesia, Imparsial, Jakarta, 2004.

Yunhu, Dong and Jian, Chang, 60 Years of Human Rights Construction in China, Jiangxi People's Publishing House, Jiangxi, 2009.

\section{Periodicals}

Gui, Huang, "Death Penalty in China after the Ninth Amendment: Legislatively Abolishing and Judicially Limiting", Journal of Forensic Science and Criminology, Volume 4, Issue 3, 2016. 
Heping, Dong, "Some Thoughts on the Problems in China's Human Rights Protection", Law Science, No.9, 2012.

Jianping, Lu, "The Death Penalty Reform in China in Light of Human Rights", Journal of Beijing Normal University (Social Science Edition), No.3, 2015.

Johnson, David T. and Zimring, Franklin E., "Death Peanalty Lesson from Asia", The Asia-Pacific Journal, Issue. 39, Vol.7, 2009.

Junaedi, "The Existence of Human Rights Court as A National Effort to Eliminate the Severe Violation of Human Rights in Indonesia", Indonesia Law Review, Vol. 2. 2014.

Lynch, Coman, “Indonesia's Use of Capital Punishment for Drug-Trafficking Crimes: Legal Obligations, Extralegal Factors, and the Bali Nine Case", Columbia Human Rights Law Review, Vol. 40, 2009.

Zimring, Franklin E. and Johnson, David T., "Law, Society, and Capital Punishment in Asia", Punishment \& Society, No. 2, Vol. 10, 2008.

\section{Miscellaneous}

Amnesty International, Death Penalty 2015: Facts and Figures, https: / /www.amnesty.org/en/latest/news/2016/04/death-penalty-2015facts-and-figures/ (accessed January 5th, 2016).

Amnesty International, Death Sentences and Executions in 2014 (ACT 50/001/2015), https://www.amnesty.org/en/documents/act50/0001/2015/en/ (accessed January 3rd, 2016).

Amnesty International, Death Sentences and Executions in 2015(ACT 50/3487/2016), https: / /www.amnesty.org/en/documents/act50/3487/2016/en/ (accessed May 15th 2016 ).

Communist Party of China's Proposals on the Current Political Situations, http://www.china.com.cn/guoqing/2012-08/28/content_26745372.htm (accessed February 11th, 2016).

Firmly March on the Path of Socialism with Chinese Characteristics and Strive to Complete the Building of A Moderately Prosperous Society in All Respects, $18^{\text {th }}$ CPC National Congress, http:/ / news.xinhuanet.com/english/special/18cpcnc/ 2012-11/17/c_131981259_4.htm (accessed February 5th, 2016).

Hold High the Great Banner of Socialism with Chinese Characteristics and Strive for New Victories in Building a Moderately Prosperous Society in all Respects, Scientific Outlook on Development, http://news.xinhuanet.com/english/200710/24/content_6938749_11.htm (accessed February 5th, 2016).

Indonesia: Stop Imminent Excecutions, Human Right Watch, 2016, https: / / www.hrw.org/news/2016/07/27/indonesia-stop-imminentexecutions (accessed July 30th, 2016).

Information of Office of the State Council of the PRC, White Papers on Human Rights in China, http://www.chinahumanrights.org/html/2014/ WP_0724/36.html (accessed 8 January 2016).

Penal Reform International, Alternative to the Death Penalty Information Pack, http:/ / www.penalreform.org/wp- 
content/uploads/2013/06/PRI_Lifers_Info_Pack.pdf (accessed January 10th, 2016).

Resolutions of the Communist Party of China's Central Committee on Major Issues Regarding the Building of A Harmonious Socialist Society, http:/ /cpc.people.com.cn/GB/64093/64094/4932424.html (accessed March 2nd, 2016).

Shaoqi, Liu, The Political Report of CPC's $8^{\text {th }}$ National Congress, in The Selected Work of Liu Shaoqi, http://cpc.people.com.cn/GB/69112/73583/73601/ 73624/5069218.htmlm (accessed February 15th, 2016).

The CCP Central Committee Decision Concerning Some Major Questions in Comprehensively Moving Government of the Country According to the Law Forward, http://www.cssn.cn/fx/fx_ttxw/201410/t20141030_1381703. shtml (accessed February10th, 2016).

The Supreme People's Court of PRC Answering the Ten Detail Questions about the Power to Review the Death Sentences was Withdrawn, http://www.lawlib.com/fzdt/newshtml/21/20061230095003.htm (accessed March 4th, 2016).

Zemin, Jiang, Build a Well-off Society in an All-Round Way and Create a New Situation in Building Socialism with Chinese Characteristics, http://history. people.com.cn/GB/205396/15040127.html (accessed February 3rd, 2016). 